\title{
A grain-based subacute ruminal acidosis challenge causes translocation of lipopolysaccharide and triggers inflammation
}

\author{
E. Khafipour, D. O. Krause, and J. C. Plaizier ${ }^{1}$ \\ Department of Animal Science, University of Manitoba, Winnipeg, MB, Canada
}

\begin{abstract}
The effects of a grain-based subacute ruminal acidosis (SARA) challenge on translocation of lipopolysaccharide (LPS) into the peripheral circulation, acute phase proteins in blood and milk, feed intake, milk production and composition, and blood metabolites were determined in 8 lactating Holstein cows. Between wk 1 and 5 of 2 successive 6 -wk periods, cows received a total mixed ration ad libitum with a forage to concentrate (F:C) ratio of 50:50. In wk 6 of both periods, the SARA challenge was conducted by replacing $21 \%$ of the dry matter of the total mixed ration with pellets containing $50 \%$ wheat and $50 \%$ barley. Rumen $\mathrm{pH}$ was monitored continuously using indwelling $\mathrm{pH}$ probes in 4 rumen cannulated cows. Rumen fluid samples were collected $15 \mathrm{~min}$ before feed delivery and at 2, 4, 6, $12,14,16,18$, and $24 \mathrm{~h}$ after feed delivery for $2 \mathrm{~d}$ during wk 5 (control) and wk 6 (SARA). Peripheral blood samples were collected using jugular catheters $15 \mathrm{~min}$ before feeding and at 6 and $12 \mathrm{~h}$ after feeding at the same days of the rumen fluid collections. The SARA challenge significantly reduced average daily $\mathrm{pH}$ from 6.17 to 5.97 and increased the duration of rumen $\mathrm{pH}$ below $\mathrm{pH} 5.6$ from 118 to $279 \mathrm{~min} / \mathrm{d}$. The challenge reduced dry matter intake (16.5 vs. $19 \mathrm{~kg} / \mathrm{d})$, milk yield ( 28.3 vs. $31.6 \mathrm{~kg} / \mathrm{d})$, and milk fat ( 2.93 vs. $3.30 \%, 0.85$ vs. $0.97 \mathrm{~kg} / \mathrm{d}$ ), and tended to increase milk protein percentage (3.42 vs. $3.29 \%$ ), without affecting milk protein yield $(1.00$ vs. $0.98 \mathrm{~kg} / \mathrm{d})$. The challenge also increased the concentration of free LPS in rumen fluid from 28,184 to 107,152 endotoxin units $(\mathrm{EU}) / \mathrm{mL}$. This was accompanied by an increase in LPS in peripheral blood plasma ( 0.52 vs. $<0.05 \mathrm{EU} / \mathrm{mL}$ ) with a peak at $12 \mathrm{~h}$ after feeding $(0.81 \mathrm{EU} / \mathrm{mL})$. Concentrations of the acute phase proteins serum amyloid A, haptoglobin, and LPS-binding protein (LBP) in peripheral blood as well as LBP concentration in milk increased (438.5 vs. $167.4,475.6$ vs. $0,53.1$ vs. 18.2 , and 6.94 vs. $3.02 \mu \mathrm{g} /$ $\mathrm{mL}$, respectively) during SARA. The increase in LBP
\end{abstract}

Received May 23, 2008.

Accepted October 8, 2008.

${ }^{1}$ Corresponding author: plaizier@ms.umanitoba.ca in combination with the increase in LPS in peripheral blood provides additional evidence of translocation of LPS. Results suggest that the grain-based SARA challenge resulted in translocation of LPS into the peripheral circulation, and that this translocation triggered a systemic inflammatory response.

Key words: subacute ruminal acidosis, lipopolysaccharide translocation, acute phase response

\section{INTRODUCTION}

Grain-based subacute ruminal acidosis (SARA) challenge increases the concentrations of the acute phase proteins serum amyloid A (SAA) and haptoglobin (Hp) in peripheral blood of cattle (Gozho et al., 2007; Emmanuel et al., 2008; Plaizier et al., 2008). These increases in acute phase proteins, which are part of the acute phase response, indicate that SARA causes inflammation (Horadagoda et al., 1999). This inflammation could be initiated by dietary-induced damage to the gut mucosa or by translocation of immunogenic compounds into circulation, such as free LPS (Horadagoda et al., 1999).

There is substantial evidence that grain-based SARA challenge increases the content of free LPS in the rumen due to the increase in lysis of gram-negative bacteria (Gozho et al., 2007; Nagaraja and Lechtenberg, 2007; Plaizier et al., 2008). This increase in luminal LPS could increase permeability of the gut for LPS (Chin et al., 2006). Also, the barrier function of rumen epithelium may be compromised by the parakeratosis, rumenitis, and abscesses of the rumen wall that result from high rumen acidity (Kleen et al., 2003). Additionally, the high rumen osmolality that is seen during SARA can cause swelling and rupture of ruminal papillae, which will also reduce the barrier function of the rumen. Despite this, no evidence of LPS in the peripheral circulation during SARA has been found (Gozho et al., 2007). There is also inconsistency in detection of LPS in peripheral blood during experimentally induced acute ruminal acidosis (Dougherty et al., 1975; Andersen and Jarlov, 1990; Andersen et al., 1994b). In recent years, the sensitivity and accuracy of bioassays used to detect LPS in low concentrations have been substantially im- 
proved, which makes the conclusion of previous studies regarding the absence of LPS in peripheral circulation questionable. The increases in the concentrations of the acute phase proteins SAA and Hp in peripheral blood do not prove translocation of LPS, as these concentrations can increase due to other inflammatory stimuli. However, because LPS interacts with a specific acute phase protein, LPS binding protein (LBP), an increase in LBP in peripheral circulation will provide evidence of the translocation of LPS (Sriskandan and Altmann, 2008).

The main objective of this study was to determine if a grain-based SARA challenge causes translocation of LPS from the gut into peripheral circulation. This was achieved by measuring plasma LPS using a high-sensitivity assay and by monitoring LBP levels in peripheral plasma and milk. The effects of the grain-based SARA challenge on feed intake, milk production and composition, blood metabolites, and SAA and Hp in peripheral blood were also determined.

\section{MATERIALS AND METHODS}

\section{Animals, Diets, and Experimental Procedures}

Cows used in this study were housed in individual tiestalls in Glenlea Dairy Research Unit at the University of Manitoba (Winnipeg, MB, Canada) in accordance with the guidelines of the Canadian Council on Animal Care (CCAC, 1993). Eight lactating Holstein cows, 4 of which were ruminally cannulated, were used during 2 subsequent 6 -wk periods. Cows were on average 84 \pm 29 DIM (mean \pm SD) with an average milk yield of $35 \pm 3.9 \mathrm{~kg} / \mathrm{d}$ and had an average BW of $615 \pm 68$ $\mathrm{kg}$ at the beginning and $634 \pm 50 \mathrm{~kg}$ at the end of experiment. Animals were randomly allocated in 2 groups consisting of 2 cannulated and 2 noncannulated cows. During wk 1 to 5 of each 6 -wk period, cows received a TMR ad libitum with a forage to concentrate $(\mathbf{F}: \mathbf{C})$ ratio of 50:50 (Tables 1, 2, and 3), with the intention of allowing for 5 to $10 \%$ orts. During wk 6 of both periods, a SARA challenge was conducted by replacing $21 \%$ of the DM of the TMR with pellets containing $50 \%$ ground wheat and $50 \%$ ground barley, resulting in an F:C of 40:60 (Table 1). Cows had unlimited access to fresh water throughout the experiment. Data obtained from wk 5 of each period was considered as control and compared with wk 6 (SARA). Samples of diets, dietary ingredients, and orts were collected and analyzed by wet chemistry as described by Bhandari et al. (2007). The physical characteristics of wheatbarley pellets including dimension, bulk density, and water-holding capacity were determined as described by Giger-Reverdin (2000).
Table 1. Ingredients, nutrient composition, and forage to concentrate ratio $(\mathrm{F}: \mathrm{C})$ of the TMR and wheat-barley pellets (WBP)

\begin{tabular}{lccc}
\hline Item & Control diet & SARA $^{1}$ diet & WBP \\
\hline Ingredients, \% of DM & & & \\
Alfalfa silage & 25.0 & 20.0 & - \\
Barley silage & 25.0 & 20.0 & - \\
Energy supplement & 40.0 & 31.6 & - \\
Protein supplement & 10.0 & 7.8 & - \\
Ground wheat & - & 10.3 & 50.0 \\
Ground barley & - & 10.3 & 50.0 \\
F:C & $50: 50$ & $40: 60$ & $0: 100$ \\
Nutrient composition & & & \\
DM, \% & 52.4 & 60.1 & 89.2 \\
CP, \% of DM & 16.9 & 16.5 & 14.8 \\
NDF, \% of DM & 35.7 & 30.4 & 11.4 \\
ADF, \% of DM & 24.3 & 22.7 & 5.7 \\
NFC $\%$ of DM & 32.7 & 40.4 & 68.6 \\
Starch, \% of DM & 26.1 & 33.4 & 60.7 \\
Crude fat, \% of DM & 5.3 & 4.5 & 2.2 \\
Ash, \% of DM & 9.4 & 8.2 & 3.0 \\
Ca, \% of DM & 1.11 & 0.92 & 0.22 \\
P, \% of DM & 0.53 & 0.52 & 0.54 \\
K, \% of DM & 1.91 & 1.60 & 0.56 \\
Mg, \% of DM & 0.32 & 0.32 & 0.16 \\
Na, \% of DM & 0.32 & 0.26 & 0.03 \\
Predicted NE ${ }^{3}$ & & & \\
Mcal/kg of DM & 1.57 & 1.66 & - \\
\hline
\end{tabular}

${ }^{1}$ Subacute ruminal acidosis.

${ }^{2} \mathrm{NFC}=100-(\mathrm{NDF} \%+\mathrm{CP} \%+$ crude fat $\%+$ ash $\%)$.

${ }^{3} \mathrm{NE}_{\mathrm{L}}$ values were predicted using CNCPS (Cornell Net Carbohydrate and Protein System) software version 5.0.4, Cornell University, Ithaca, NY.

\section{Rumen pH Measurement}

Rumen $\mathrm{pH}$ was monitored continuously for 4 consecutive days during wk 5 and wk 6 of both experimental periods in 4 rumen cannulated cows using indwelling $\mathrm{pH}$ probes as described by Gozho et al. (2006). The $\mathrm{pH}$ data were summarized as average $\mathrm{pH}$, time spent below $\mathrm{pH} 6.0$, time spent below $\mathrm{pH} 5.6$, area (time $\times$ $\mathrm{pH})$ spent below $\mathrm{pH} 6.0$, and area spent below $\mathrm{pH} 5.6$ for each 24 -h period.

\section{Rumen Sampling and Analysis}

Rumen fluid samples were collected from the ventral sac of the rumen of rumen cannulated cows $15 \mathrm{~min}$ before feed delivery and at 2, 4, 6, 12, 14, 16, 18, and 24 $\mathrm{h}$ after feed delivery on 2 consecutive days of each sampling week. Ruminal contents were strained through 4 layers of sterile cheesecloth and divided into 2 portions. The first portion of samples were transferred into 50-mL sterile tubes and kept on ice until transported to the laboratory for the initial processing before LPS determination as described by Gozho et al. (2005). In brief, rumen fluid samples were centrifuged at 10,000 $\times$ $g$ for $45 \mathrm{~min}$. The supernatant was aspirated gently to prevent its mixing with the pellet and passed through 
Table 2. Nutrient composition of the forages and supplements

\begin{tabular}{lcccc}
\hline Item & Energy supplement & Protein supplement & Barley silage & Alfalfa silage \\
\hline $\mathrm{DM}, \%$ & 90.4 & 91.7 & 26.5 & 57.5 \\
$\mathrm{CP}, \%$ of DM & 18.4 & 31.1 & 11.1 & 19.6 \\
$\mathrm{NDF}, \%$ of DM & 16.2 & 42.4 & 55.5 & 48.3 \\
$\mathrm{ADF}, \%$ of DM & 9.2 & 15.5 & 40.9 & 33.7 \\
NFC,$\%$ of DM & 53.6 & 2.9 & 18.8 & 19.5 \\
Starch, \% of DM & 35.9 & 2.5 & 11.3 & 12.2 \\
Crude fat, \% of DM & 5.0 & 6.7 & 3.0 & 1.9 \\
Ash, \% of DM & 6.8 & 16.9 & 11.6 & 10.7 \\
Ca, \% of DM & 0.82 & 3.11 & 0.39 & 1.04 \\
P, \% of DM & 0.68 & 1.07 & 0.39 & 0.41 \\
K, \% of DM & 0.97 & 1.00 & 2.29 & 2.99 \\
Mg, \% of DM & 0.30 & 0.29 & 0.31 & 0.37 \\
$\mathrm{Na}, \%$ of DM & 0.30 & 1.70 & 0.06 & 0.12 \\
\hline
\end{tabular}

${ }^{1} \mathrm{NFC}=100-(\mathrm{NDF} \%+\mathrm{CP} \%+$ crude fat $\%+$ ash $\%)$.

a disposable 0.22- $\mu \mathrm{m}$ LPS-free filter (Millex, Millipore Corporation, Bedford, MA). The filtrate was collected in a sterile, depyrogenated glass tube (previously heated at $180^{\circ} \mathrm{C}$ for $4 \mathrm{~h}$ ) and heated at $100^{\circ} \mathrm{C}$ for 30 min. Samples were cooled at room temperature $\left(19^{\circ} \mathrm{C}\right)$ for $10 \mathrm{~min}$ and stored at $-20^{\circ} \mathrm{C}$ for subsequent LPS measurement. The second portion of the rumen fluid samples were immediately centrifuged at $1,900 \times g$ for $15 \mathrm{~min}$ and the supernatant was stored at $-20^{\circ} \mathrm{C}$ until analyzed for osmolality, VFA, lactate, and ammonia.

Free Rumen LPS. Free rumen LPS content was determined by a chromogenic Limulus amoebocyte lysate (LAL) end-point assay (QCL-1000, Lonza Group Ltd., Basel, Switzerland). Pretreated rumen samples were diluted until their LPS concentrations were in the range of 0.1 to 1 endotoxin units $(\mathbf{E U}) / \mathrm{mL}$ relative to the reference endotoxin (Escherichia coli O111:B4), and assayed as described by Gozho et al. (2005).
Rumen VFA, Lactate, Ammonia, and Osmolality. Concentrations of VFA (acetate, propionate, butyrate, valerate, isobutyrate, and isovalerate) and lactate were determined by gas chromatography (Model 3400 Star, Varian, Walnut Creek, CA) as described by Bhandari et al. (2007) with some modifications. In brief, rumen fluid samples were thawed at room temperature and $1 \mathrm{~mL}$ of $25 \%$ meta-phosphoric acid solution was added to $5 \mathrm{~mL}$ of rumen fluid. The tubes were vortexed and stored at $-20^{\circ} \mathrm{C}$ overnight. Samples were thawed again, and $0.4 \mathrm{~mL}$ of $25 \%$ sodium hydroxide and 0.64 $\mathrm{mL}$ of $0.3 \mathrm{M}$ oxalic acid were added to the tubes and vortexed each time. The tubes were centrifuged at $3,000 \times g$ for $20 \mathrm{~min}$ and $2 \mathrm{~mL}$ of supernatants were transferred into gas chromatography vials for analysis. Ammonia nitrogen concentration of rumen fluid samples was determined using a colorimetric technique as described by Bhandari et al. (2007). Osmolality of

Table 3. Ingredient composition of the energy and protein supplements ( $\%$ of DM)

\begin{tabular}{|c|c|c|}
\hline Ingredient & Energy supplement & Protein supplement \\
\hline Rolled barley & 54.0 & - \\
\hline Luprosil salt (calcium propionate) & 0.2 & - \\
\hline Protein pellet $^{1}$ & 1.8 & - \\
\hline Dairy supplement ${ }^{2}$ & 40.0 & - \\
\hline Vegetable oil & 4.0 & - \\
\hline Corn dried distillers with solubles & - & 42.0 \\
\hline Fish meal & - & 7.0 \\
\hline Canola meal & - & 22.7 \\
\hline Soybean meal & - & 20.0 \\
\hline Beet molasses & - & 3.0 \\
\hline Niacin & - & 0.3 \\
\hline Sodium bicarbonate & - & 5.0 \\
\hline \multicolumn{3}{|c|}{$\begin{array}{l}{ }^{1} \text { Protein pellets contain } 46.1 \% \text { soybean meal, } 2.6 \% \text { wheat shorts, } 40 \% \text { canola meal, } 5 \% \text { oat hulls, } 0.3 \% \text { pelle } \\
\text { binder, } 1 \% \text { cane molasses, and } 5 \% \text { corn gluten meal. }\end{array}$} \\
\hline \multicolumn{3}{|c|}{$\begin{array}{l}{ }^{2} \text { Dairy supplement contains } 0.13 \% \text { vitamin } \mathrm{A}, \mathrm{D} \text {, and } \mathrm{E} \text { premix (vitamin } \mathrm{A}, 16,800 \mathrm{IU} / \mathrm{kg} \text {; vitamin } \mathrm{D}, 2,215 \mathrm{IU} / \\
\mathrm{kg} \text {; vitamin } \mathrm{E}, 75 \mathrm{IU} / \mathrm{kg}, \mathrm{DM} \text { basis), } 0.13 \% \text { trace mineral premix, } 2.6 \% \text { soybean meal, } 0.06 \% \text { selenium, } 39.1 \% \\
\text { wheat shorts, } 5 \% \text { distillers grains, } 17.5 \% \text { canola meal, } 15 \% \text { ground wheat, } 1.7 \% \text { dicalcium phosphate, } 1.6 \% \\
\text { salt, } 2 \% \text { Dynamate (Mosaic Company, Plymouth, MN), } 0.3 \% \text { pellet binder, } 1 \% \text { cane molasses, } 3.7 \% \text { calcium } \\
\text { carbonate, and } 10 \% \text { corn gluten meal. }\end{array}$} \\
\hline
\end{tabular}


rumen fluid samples was determined by freezing point depression using an automatic osmometer (Advanced single sample micro-osmometer model 3300, Advanced Instruments Inc., Norwood, MA).

\section{Blood Sampling and Analysis}

Blood samples were collected using jugular catheters $15 \mathrm{~min}$ before feeding and at 6 and $12 \mathrm{~h}$ after feed delivery on 2 subsequent days in each sampling week. Catheters and their extenders were filled with sterile, heparinized $0.9 \%$ saline $(5,000 \mathrm{IU} / 100 \mathrm{~mL})$ to prevent clotting after each sampling. Samples were collected in a blank 10-mL vacutainer (Fisher Scientific, Fairlawn, $\mathrm{NJ}$ ) for serum harvesting and in a $10-\mathrm{mL}$ heparinized vacutainer (Fisher Scientific) for plasma collection. The serum vacutainers were allowed to clot at room temperature $\left(19^{\circ} \mathrm{C}\right)$ for $45 \mathrm{~min}$, and then centrifuged at $1,900 \times g$ for 15 min. Subsequently, serum was aspirated and stored in $-20^{\circ} \mathrm{C}$ until used for $\mathrm{Hp}$ analysis. Plasma was harvested by centrifuging of heparinized vacutainers at $1,900 \times g$ for $15 \mathrm{~min}$. A portion of plasma was transferred to pyrogen-free glass tubes and stored at $-20^{\circ} \mathrm{C}$ for LPS analysis. The remaining plasma was divided into $2-\mathrm{mL}$ aliquots and stored at $-20^{\circ} \mathrm{C}$ until analyzed for SAA, LBP, glucose, and lactate. Plasma glucose and lactate were analyzed using a blood gas and electrolyte analyzer (Nova Stat Profile M, Nova Biomedical Corporation, Waltham, MA) as described by Bhandari et al. (2007).

LPS Analysis in Blood Plasma. The concentration of LPS in plasma was determined by a chromogenic kinetic LAL assay (Kinetic-QCL, Lonza Group Ltd.) with a minimum detection limit of $0.005 \mathrm{EU} /$ $\mathrm{mL}$. Samples were initially treated as recommended by Dosogne et al. (2002) and Hurley (1995) with some modifications to inactivate inhibitory factors in plasma. In brief, frozen plasma samples were thawed at $37^{\circ} \mathrm{C}$, vortexed, and $100 \mu \mathrm{L}$ of each sample were diluted at least 10-fold with LAL water. Diluted samples were incubated at $37^{\circ} \mathrm{C}$ for $30 \mathrm{~min}$, then heated at $75^{\circ} \mathrm{C}$ for $15 \mathrm{~min}$ and cooled to room temperature $\left(19^{\circ} \mathrm{C}\right)$ for 45 min. Then, a metallo-modified polyanionic dispersant called Pyrosperse (Lonza Group Ltd.) was added to the test samples at a ratio of $1 / 200(\mathrm{vol} / \mathrm{vol})$ before LAL testing. The kinetic LAL assay was performed in a 96well microplate. The appearance of a yellow color was monitored over time using an incubating microplate spectrophotometer (Spectra Max 340 PC, Molecular Devices Corporation, Sunnyvale, CA) to determine the reaction time, which is defined as the time required for absorbance to increase 0.2 optical density. A $\log$ / log linear correlation of the mean reaction time of each standard with its corresponding endotoxin concentra- tion was performed to create a standard curve and predict endotoxin concentration of test samples. To verify the lack of product inhibition, samples were spiked with $10 \mu \mathrm{L}$ of $2 \mathrm{EU} / \mathrm{mL}$ standard. A recovery range between 50 to $150 \%$ of the spiked concentration was considered as noninhibitory dilution. All samples were tested in duplicate and results were accepted when intraassay CV was less than $10 \%$. With regard to initial 10-fold dilution of samples, the minimum detection level of LPS in plasma was $0.05 \mathrm{EU} / \mathrm{mL}$ with this method.

Blood Acute Phase Proteins. Serum concentrations of $\mathrm{Hp}$ and plasma concentrations of SAA were determined using ELISA kits (TP-801 and TP-802, respectively, Tri-Delta Diagnostics Inc., Morris Plains, NJ) as described by Gozho et al. (2005). Plasma concentrations of LBP were measured using a commercially available kit (HK503, HyCult Biotechnology, Uden, the Netherlands). Samples were initially diluted 1:5 for Hp, 1:500 for SAA, and 1:1,000 for LBP. Samples were analyzed in duplicate and absorbance values were read at $630 \mathrm{~nm}$ for $\mathrm{Hp}$, and $450 \mathrm{~nm}$ for SAA, and LBP using a microplate spectrophotometer (Spectra Max 340 PC, Molecular Devices Corporation; and BioRad model 3550, Hercules, CA, respectively). The minimum detection limits of these assays were $50 \mu \mathrm{g} / \mathrm{mL}, 0.3 \mu \mathrm{g} / \mathrm{mL}$, and $1.6 \mathrm{ng} / \mathrm{mL}$ for $\mathrm{Hp}$, SAA, and LBP, respectively.

\section{Milk Sampling and Analysis}

Cows were milked twice daily in their stall at approximately 0400 and $1600 \mathrm{~h}$. Milk yield was recorded and milk samples from 4 consecutive milkings during each sampling week were collected and analyzed as described by Bhandari et al. (2007). The exception to this was that at each milking a second milk sample $(10 \mathrm{~mL})$ was taken without preservative and stored at $-20^{\circ} \mathrm{C}$ for LBP analysis.

Milk $\mathbf{L} \boldsymbol{B P}$. Frozen milk samples were thawed at room temperature $\left(19^{\circ} \mathrm{C}\right)$ and a $2-\mathrm{mL}$ portion was centrifuged at $20,000 \times g$ at $4^{\circ} \mathrm{C}$ for $1 \mathrm{~h}$. After removing the fat layer, the samples were centrifuged 2 more times as indicated above, and the supernatant was collected and stored in $-80^{\circ} \mathrm{C}$ until analyzed for LBP as described for plasma LBP.

\section{Statistical Analysis}

Data collected from wk 5 (control) and wk 6 (SARA) of each period were analyzed with repeated measures using PROC MIXED (SAS Institute, 2004). For intake, milk production, and rumen $\mathrm{pH}$ parameters, the effect of diet (control or SARA) and period were considered fixed. Because the effects of period were not significant, it was excluded from the final statistical model. The 
Table 4. Feed intake, milk yield, and milk composition in dairy cows fed a basal diet during control or a diet with wheat-barley pellets (WBP) during a grain-based SARA challenge

\begin{tabular}{|c|c|c|c|c|c|c|}
\hline Item & \multicolumn{2}{|c|}{ Diet } & $\mathrm{SED}^{2}$ & \multicolumn{3}{|c|}{ Effect, $P$-value } \\
\hline $\mathrm{kg}$ of TMR DM/d & 19.0 & 13.1 & 0.5 & $<0.0001$ & 0.33 & 0.8 \\
\hline $\mathrm{kg}$ of WBP DM/d & 0.00 & 3.45 & 0.16 & $<0.0001$ & 0.003 & 0.003 \\
\hline Orts, $\%$ of feed provided & 12.6 & 28.3 & 2.1 & 0.0003 & 0.14 & 0.3 \\
\hline Fat, $\%$ & 3.30 & 2.93 & 0.09 & 0.003 & 0.28 & $<0.01$ \\
\hline Fat yield, $\mathrm{kg} / \mathrm{d}$ & 0.97 & 0.85 & 0.05 & 0.03 & 0.05 & 0.47 \\
\hline Protein, $\%$ & 3.29 & 3.42 & 0.07 & 0.08 & 0.09 & 0.08 \\
\hline Protein yield, $\mathrm{kg} / \mathrm{d}$ & 0.98 & 1.00 & 0.03 & 0.56 & 0.19 & 0.42 \\
\hline
\end{tabular}

${ }^{1}$ Subacute ruminal acidosis.

${ }^{2} \mathrm{SED}=$ standard error of difference between treatments.

effects of cow, period, period $\times$ cow, diet $\times$ period $\times$ cow, and day within diet and period were considered random. Day within diet and period was considered a repeated measure. For rumen and blood metabolites, additional effect of postfeeding hours and its interaction with diet were considered fixed, and hour $\times$ day interaction within diet and period were considered random. To obtain a normal distribution and homogeneous residual error, ruminal LPS data were log-transformed. Tukey's multiple range test was used to compare the differences among treatment means. Effects were considered significant at $P<0.05$. Trends were discussed at $P<0.10$.

\section{RESULTS}

The health of animals was monitored daily by checking feed consumption and rumen $\mathrm{pH}$. Induction of SARA during the first day of period 1 resulted in an excessive reduction of DMI $(>50 \%)$ and rumen $\mathrm{pH}(<\mathrm{pH} 5)$ in 2 of the cows. The data from d 1 and the next 2 following days of those cows in period 1 were excluded from the statistical analysis.

\section{Diets, Feed Intake, Milk Yield, and Milk Composition}

Replacing $21 \%$ of the DM of the TMR with wheatbarley pellets resulted in an average daily consumption of $3.5 \mathrm{~kg}$ (DM basis) of wheat-barley pellets. This replacement changed the chemical composition of the diet toward greater DM (60.1 vs. $52.4 \%$ ), NFC (40.4 vs. $32.7 \%$ ), and starch (33.4 vs. $26.1 \%$ ), and less CP (16.5 vs. $16.9 \%$ ), NDF (30.4 vs. $35.7 \%$ ), and $\mathrm{ADF}$ (22.7 vs. $24.3 \%$ ) (Table 1). The mean and standard deviation of wheat-barley pellets length, diameter, bulk density, and water-holding capacity were $9.51 \pm 2.83 \mathrm{~mm}, 4.15 \pm$ $0.11 \mathrm{~mm}, 1.29 \mathrm{~g} / \mathrm{mL}$, and $2.21 \mathrm{~g} / \mathrm{g}$, respectively.
The DMI was decreased by $15 \%$ following the inclusion of wheat-barley pellets in the diet $(P=0.007$; Table 4). The average DMI was 19.0 and $16.5 \mathrm{~kg} / \mathrm{d}$ for the control and SARA cows, respectively. No significant effect of day or its interaction with diet with respect to DMI were detected ( $P=0.16$ and 0.49 , respectively). Across cows, day-to-day variation in DMI was limited during the control weeks ranging from 18.6 to $19.6 \mathrm{~kg} / \mathrm{d}$ (Figure 1). However, on average, the DMI declined during the first $2 \mathrm{~d}$ of SARA from $18.7 \mathrm{~kg} / \mathrm{d}$ to 15.9 and $14.8 \mathrm{~kg} / \mathrm{d}$, respectively, but then increased to 17.1 and $18.2 \mathrm{~kg} / \mathrm{d}$ during the next $2 \mathrm{~d}$, and decreased again to $16.5 \mathrm{~kg} / \mathrm{d}$ on d 5 of SARA (Figure 1).

Milk yield tended to decline from 31.6 to $28.3 \mathrm{~kg} / \mathrm{d}$ in response to the grain-based SARA challenge $(P=$ 0.07 ; Table 4$)$. The effects of day $(P=0.001)$ and its interaction with diet on milk yield were significant $(P$ $=0.002)$. Milk yield on the first day of the ruminal

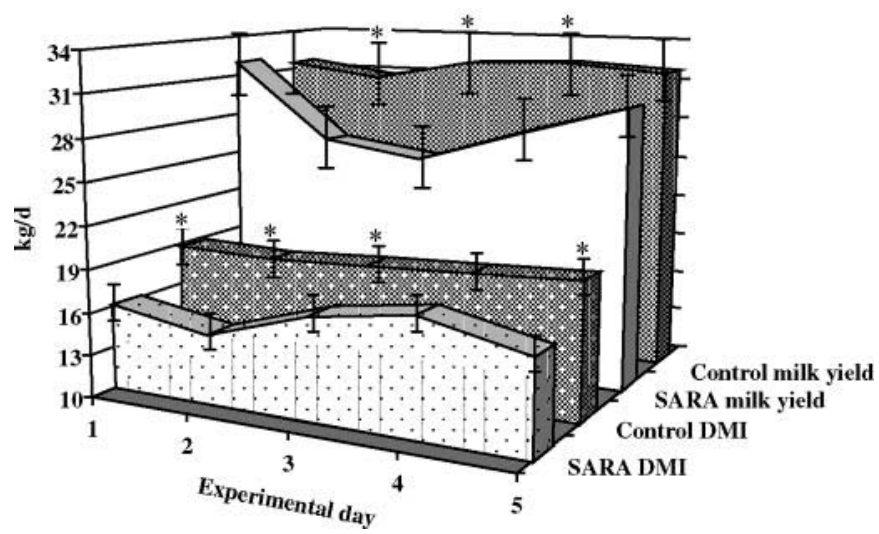

Figure 1. Daily averages of DMI and milk yield in dairy cows fed a basal TMR during control or TMR with wheat-barley pellets during subacute ruminal acidosis (SARA) treatment. Error bars indicate standard error of difference between treatments (SED); within each day, ${ }^{*}=P<0.05$. 
Table 5. Rumen $\mathrm{pH}$ variables in dairy cows in dairy cows fed a basal diet during control or a diet with wheatbarley pellets during a grain-based SARA challenge

\begin{tabular}{|c|c|c|c|c|c|c|}
\hline \multirow[b]{2}{*}{ Item } & \multicolumn{2}{|c|}{ Diet } & \multirow[b]{2}{*}{$\mathrm{SED}^{2}$} & \multicolumn{3}{|c|}{ Effect, $P$-value } \\
\hline & Control & SARA $^{1}$ & & Diet & Day & Diet $\times$ Day \\
\hline Average $\mathrm{pH}$ & 6.17 & 5.97 & 0.07 & 0.03 & 0.83 & 0.82 \\
\hline Time $<\mathrm{pH} 5.6, \mathrm{~min} / \mathrm{d}$ & 118 & 279 & 47 & 0.01 & 0.53 & 0.28 \\
\hline Time $<\mathrm{pH} 6.0, \mathrm{~min} / \mathrm{d}$ & 490 & 678 & 69 & 0.03 & 0.77 & 0.63 \\
\hline Area $<\mathrm{pH} 5.6, \min \times \mathrm{pH} / \mathrm{d}$ & 15 & 102 & 38 & 0.05 & 0.30 & 0.37 \\
\hline Area $<\mathrm{pH} 6.0, \min \times \mathrm{pH} / \mathrm{d}$ & 127 & 288 & 52 & 0.02 & 0.42 & 0.36 \\
\hline
\end{tabular}

${ }^{1}$ Subacute ruminal acidosis.

${ }^{2} \mathrm{SED}=$ standard error of difference between treatments.

acidosis challenge was similar to the control $(P=0.82)$ and averaged $31.8 \mathrm{~kg} / \mathrm{d}$ across treatments, but declined until $\mathrm{d} 3$ to $25.4 \mathrm{~kg} / \mathrm{d}$, and then increased during the last $2 \mathrm{~d}$ of SARA and reached $29.9 \mathrm{~kg} / \mathrm{d}$ (Figure 1). This challenge also significantly reduced milk fat $(2.93$ vs. $3.3 \%, P=0.003)$ and fat yield (0.85 vs. $0.97 \mathrm{~kg} / \mathrm{d}$, $P=0.03)$, but tended to increase milk protein percentage (3.42 vs. $3.29 \%, P=0.08)$ without affecting milk protein yield ( 1.00 vs. $0.98 \mathrm{~kg} / \mathrm{d}, P=0.56$; Table 4$)$.

\section{Ruminal Parameters}

Continuous rumen $\mathrm{pH}$ monitoring during wk 5 and 6 indicated that the SARA challenge reduced average daily $\mathrm{pH}$ from 6.17 to $5.97(P=0.03)$ and increased the duration of rumen $\mathrm{pH}$ below 5.6 from 118 to 279 $\mathrm{min} / \mathrm{d}(P=0.01$; Table 5$)$. This duration was above $180 \mathrm{~min} / \mathrm{d}$, which was taken as the threshold for SARA. The SARA challenge also increased the duration of rumen $\mathrm{pH}$ below 6 from 490 to $678 \mathrm{~min} / \mathrm{d}(P=0.03)$ and areas below $\mathrm{pH} 6$ and 5.6 from 127 to $288 \mathrm{~min} \times \mathrm{pH} / \mathrm{d}$, and from 15 to $102 \mathrm{~min} \times \mathrm{pH} / \mathrm{d}$, respectively $(P=0.02$ and 0.05 , respectively; Table 5 ).

Feeding wheat-barley pellets increased the daily averages of rumen propionate (34.7 vs. $22.4 \mathrm{mM}, P=$ 0.0005 ), butyrate (14.6 vs. $11.2 \mathrm{mM}, P=0.04$ ), and valerate (2.6 vs. $1.4 \mathrm{~m} M, P=0.02)$, but reduced rumen acetate (54 vs. $61.9 \mathrm{mM}, P=0.02$ ) and the acetate to propionate ratio (1.61 vs. $2.86, P=0.0003$; Table $6)$. The daily averages of total VFA and osmolality in the rumen tended to be higher (107.3 vs. $98.5 \mathrm{mM}$ and 294.6 vs. $279.4 \mathrm{mOsm} / \mathrm{kg}$, respectively) in SARA cows $(P=0.07)$ (Tables 6 and 7$)$. However, addition of wheat-barley pellets to the diet did not affect the daily averages of total branched-chain VFA (isobutyrate + isovalerate), lactate, and ammonia in the rumen, which averaged $1.58 \mathrm{~m} M, 1.97 \mathrm{mM}$, and $9.3 \mathrm{mg} / \mathrm{dL}$ across treatments, respectively. Concentrations of VFA, but not that of lactate, were significantly affected by hours postfeeding (Table $6 ; P<0.0001$ ).
Across hours postfeeding, the grain-based SARA challenge increased ruminal LPS concentration from 28,184 to $107,152 \mathrm{EU} / \mathrm{mL}(P=0.004$; Table 7$)$. The LPS concentration was also affected by hours postfeeding $(P=0.0005)$ and its interaction with $\operatorname{diet}(P=$ 0.025; Table 7). During the control treatment, LPS concentration did not vary significantly throughout the 24 -h period. However, during the SARA challenge, it increased from 73,283 before feeding to $109,320 \mathrm{EU} / \mathrm{mL}$ at $6 \mathrm{~h}$ postfeeding $(P=0.005)$, and reached a peak of $151,985 \mathrm{EU} / \mathrm{mL}$ at $12 \mathrm{~h}$ postfeeding $(P=0.02$; Table 7).

\section{Blood and Milk Parameters}

Plasma LPS concentration in control cows was below the minimum detection level of $0.05 \mathrm{EU} / \mathrm{mL}$ for the method (Table 7). Following the SARA challenge the average LPS in plasma increased to $0.52 \mathrm{EU} / \mathrm{mL}$. Hours postfeeding tended to influence plasma LPS $(P$ $=0.1$ ) in SARA cows, as LPS declined to below prefeeding levels ( 0.31 vs. $0.43 \mathrm{EU} / \mathrm{mL}$ ) by 6 h postfeeding and then increased to $0.81 \mathrm{EU} / \mathrm{mL}$ at $12 \mathrm{~h}$ postfeeding (Table 7).

In response to the grain-based SARA challenge, blood concentrations of the acute phase proteins $\mathrm{Hp}$, SAA, and LBP were increased from 0 to $475.6 \mu \mathrm{g} / \mathrm{mL}$ $(P=0.001)$, from 167.4 to $438.5 \mu \mathrm{g} / \mathrm{mL}(P=0.01)$, and from 18.2 to $53.1 \mu \mathrm{g} / \mathrm{mL}(P=0.018)$, respectively (Table 8 ). This challenge also increased milk LBP concentration from 3.02 to $6.94 \mu \mathrm{g} / \mathrm{mL}(P=0.02)$. The effects of hours postfeeding or its interaction with diet on Hp and SAA levels were not significant (Table 8).

Across hours postfeeding, the SARA challenge increased blood glucose concentration (73 vs. $66.7 \mathrm{mg}$ / $\mathrm{dL}, P=0.0008)$, but did not affect blood lactate $(0.8$ vs. $1.4 \mathrm{~m} M, P=0.27$; Table 6$)$. Averaged across treatments, glucose concentration increased from $66.5 \mathrm{mg} /$ $\mathrm{dL}$ before feeding to $72.6 \mathrm{mg} / \mathrm{dL}$ at $12 \mathrm{~h}$ postfeeding $(P=0.0001)$. 
Table 6. Rumen fluid composition and blood metabolites of dairy cows fed a basal diet during control or a diet with wheat-barley pellets during a grain-based SARA challenge

\begin{tabular}{|c|c|c|c|c|c|c|}
\hline Item $^{1}$ & \multicolumn{2}{|c|}{ Diet } & $\mathrm{SED}^{3}$ & \multicolumn{3}{|c|}{ Effect, $P$-value } \\
\hline \multicolumn{7}{|l|}{ Ruminal parameters } \\
\hline Total & 98.5 & 107.3 & 3.7 & 0.07 & $<0.0001$ & 0.75 \\
\hline Acetate & 61.9 & 54.0 & 2.1 & 0.02 & $<0.0001$ & 0.72 \\
\hline Propionate & 22.4 & 34.7 & 2.3 & 0.0005 & $<0.0001$ & 0.26 \\
\hline Total branched-chain $\mathrm{VFA}^{5}$ & 1.69 & 1.47 & 0.15 & 0.23 & $<0.0001$ & 0.33 \\
\hline Acetate: Propionate & 2.86 & 1.61 & 0.16 & 0.0003 & $<0.0001$ & 0.04 \\
\hline Lactate, $\mathrm{m} M$ & 1.65 & 2.29 & 0.47 & 0.25 & 0.33 & 0.96 \\
\hline Ammonia, mg/dL & 8.8 & 9.8 & 1.8 & 0.62 & $<0.001$ & 0.46 \\
\hline \multicolumn{7}{|l|}{ Blood parameters } \\
\hline Glucose, mg/dL & 66.7 & 73.0 & 1.0 & 0.0008 & $<0.001$ & 0.1 \\
\hline Lactate, $\mathrm{m} M$ & 1.4 & 0.8 & 0.5 & 0.27 & 0.07 & 0.68 \\
\hline
\end{tabular}

${ }^{1}$ Daily concentration mean across sampling times.

${ }^{2}$ Subacute ruminal acidosis.

${ }^{3} \mathrm{SED}=$ standard error of difference between treatments.

${ }^{4}$ Hour $=$ time of rumen fluid sampling before and at $2,4,6,12,14,16,18$, and $24 \mathrm{~h}$ after feeding in two consecutive days during each sampling week. The first day of sampling is three days after induction of SARA during SARA treatment.

${ }^{5}$ Total branched-chain $=$ isobutyrate + isovalerate.

\section{DISCUSSION}

Earlier research has shown that successful induction of SARA, which is characterized by feed intake depression and inflammation, only occurs when a rumen $\mathrm{pH}$ depression between 5.2 and 5.6 is obtained for more than $180 \mathrm{~min} / \mathrm{d}$ (Gozho et al., 2005). Replacing $21 \%$ of the DM of the TMR with wheat-barley pellets in this study resulted in average duration of rumen $\mathrm{pH}<5.6$ for $279 \mathrm{~min} / \mathrm{d}$, which was in agreement with 506 and
$309 \mathrm{~min} / \mathrm{d}$ reported by Krause and Oetzel (2005) and Gozho et al. (2007), respectively, for SARA induced cows. The area under $\mathrm{pH} 5.6$ in the current study was $102 \mathrm{~min} \times \mathrm{pH} / \mathrm{d}$, which was close to 190 and $67 \mathrm{~min} \times$ $\mathrm{pH} / \mathrm{d}$ reported by Krause and Oetzel (2005) and Gozho et al. (2007), respectively. We therefore conclude that SARA was successfully induced in the present study.

Feeding wheat-barley pellets depressed DMI by $15 \%$ compared with the control group. This reduction in DMI can be due to hypophagic effects of elevated levels of

Table 7. Plasma LPS and rumen fluid LPS and osmolality in dairy cows fed a basal diet during control or a diet with wheat-barley pellets during a grain-based SARA challenge

\begin{tabular}{|c|c|c|c|c|c|c|}
\hline Item & \multicolumn{2}{|c|}{ Diet } & $\mathrm{SED}^{2}$ & \multicolumn{3}{|c|}{ Effect, $P$-value } \\
\hline \multicolumn{7}{|c|}{ Plasma LPS, EU/mL ${ }^{4}$} \\
\hline $0 \mathrm{~h}$ & $<0.05^{5}$ & 0.43 & 0.18 & 0.001 & 0.16 & 0.1 \\
\hline $6 \mathrm{~h}$ & $<0.05$ & 0.31 & & & & \\
\hline $12 \mathrm{~h}$ & $<0.05$ & 0.81 & & & & \\
\hline \multicolumn{7}{|c|}{ Rumen LPS, EU/mL ${ }^{6}$} \\
\hline $12 \mathrm{~h}$ & 29,492 & 151,985 & & & & \\
\hline \multicolumn{7}{|c|}{ Rumen osmolality, mOsm $/ \mathrm{kg}$} \\
\hline $0 \mathrm{~h}$ & 263 & 257 & 7.1 & 0.07 & 0.0002 & 0.06 \\
\hline $6 \mathrm{~h}$ & 296 & 332 & & & & \\
\hline
\end{tabular}

${ }^{1}$ Subacute ruminal acidosis.

${ }^{2} \mathrm{SED}=$ standard error of difference between treatments.

${ }^{3}$ Hour $=$ time of sampling before and at 6 and $12 \mathrm{~h}$ after feeding in 2 consecutive days during each sampling week. The first day of sampling is $3 \mathrm{~d}$ after induction of SARA during SARA weeks.

${ }^{4} \mathrm{EU}=$ endotoxin unit.

${ }^{5}$ The minimum detection level of plasma LPS with this method was $0.05 \mathrm{EU} / \mathrm{mL}$.

${ }^{6}$ Statistical analyses were conducted on $\log _{10}$-transformed data. 
Table 8. Serum amyloid A (SAA), haptoglobin (Hp), and LPS binding protein (LBP) concentrations in blood or milk of dairy cows fed a basal diet during control or a diet with wheat-barley pellets during a grain-based SARA challenge

\begin{tabular}{|c|c|c|c|c|c|c|}
\hline Item & \multicolumn{2}{|c|}{ Diet } & $\mathrm{SED}^{2}$ & \multicolumn{3}{|c|}{ Effect, $P$-value } \\
\hline $6 \mathrm{~h}$ & 164.4 & 446.7 & & & & \\
\hline \multicolumn{7}{|l|}{ Serum Hp, $\mu \mathrm{g} / \mathrm{mL}$} \\
\hline $0 \mathrm{~h}$ & $\mathrm{ND}^{4}$ & 468 & 48.0 & 0.001 & 0.33 & 0.33 \\
\hline $6 \mathrm{~h}$ & 18.2 & 53.1 & 10.8 & 0.018 & - & - \\
\hline \multicolumn{7}{|l|}{ Milk LBP, $\mu \mathrm{g} / \mathrm{mL}$} \\
\hline $6 \mathrm{~h}$ & 3.02 & 6.94 & 1.24 & 0.02 & - & - \\
\hline
\end{tabular}

${ }^{1}$ Subacute ruminal acidosis.

${ }^{2} \mathrm{SED}=$ standard error of difference between treatments.

${ }^{3}$ Hour $=$ time of sampling before and at $6 \mathrm{~h}$ after feeding. Samples are collected $4 \mathrm{~d}$ after induction of SARA during SARA weeks.

${ }^{4} \mathrm{ND}=$ nondetectable with the minimum detection limit of $50 \mu \mathrm{g} / \mathrm{mL}$.

propionate in the rumen and glucose in blood (Oba and Allen, 2003), as well as the hyperosmolality of rumen, dehydration (Allen, 2000), and endotoxemia (Waldron et al., 2003) that were observed during the current study. There is a general agreement that reduced or erratic feed intake is a consistent sign of SARA in dairy cows (Owens, et al., 1998; Kleen et al., 2003; Plaizier et al., 2008) and beef cattle (Nagaraja and Lechtenberg, 2007). However, several studies did not observe such a reduction during experimental grain-induced SARA (Krause and Oetzel, 2005; Gozho et al., 2006, 2007). This discrepancy might be related to insulin, as cows with higher plasma insulin before high starch treatments or lower insulin secretion in response to glucose showed greater depression in feed intake (Bradford and Allen, 2007). Other reasons for this discrepancy might include differences in the contents of fiber and ensiled forages, in particle size and in starch fermentability among the diets used to induce SARA (Allen, 2000), as well as differences in endotoxin tolerance among individual cows (Hurley, 1995).

The hypothesis that free rumen LPS concentration increases following grain engorgement (Andersen et al., 1994a; Emmanuel et al., 2008), especially during experimentally induced acute acidosis (Andersen and Jarlov, 1990; Andersen et al., 1994b) or SARA (Gozho et al., 2005; 2006; 2007), has been clearly proven. However, the reported range of free LPS in rumen fluid varied substantially in these earlier studies. For the purpose of comparison among studies, LPS concentrations were converted and expressed in nanograms per milliliter. Because $1 \mathrm{EU}$ corresponds to $100 \mathrm{pg}$ of LPS, the absolute concentration of LPS in our experiment varied from $2,818 \mathrm{ng} / \mathrm{mL}$ in the control group to $10,715 \mathrm{ng} /$ $\mathrm{mL}$ in SARA cows. Similar to our results, Gozho et al.
(2007) reported an LPS range of 2,454 to $12,882 \mathrm{ng} / \mathrm{mL}$ in Holstein dairy cows (538 kg, 121 DIM) during periods of control and grain-induced SARA, respectively. A recent study by Emmanuel et al. (2008) reported an LPS range from $790 \mathrm{ng} / \mathrm{mL}$ in control to 5,021 and 8,870 $\mathrm{ng} / \mathrm{mL}$ when $30 \%$ and $45 \%$ barley was supplemented in the diet of Holstein dairy cows $(650 \mathrm{~kg}, 60$ to 140 DIM), respectively. Gozho et al. (2005; 2006) reported a lower range of LPS in Jersey steers $(678 \mathrm{~kg})$. In these studies, abrupt induction of SARA or gradual adaptation to $61 \%$ wheat-barley pellet in the diet, increased the rumen LPS from 375 to $887 \mathrm{ng} / \mathrm{mL}$ and from 631 to $871 \mathrm{ng} / \mathrm{mL}$, respectively. In contrast, Andersen et al. (1994b) reported an LPS range from 11.8 to 14.8 $\mathrm{ng} / \mathrm{mL}$ with a hay-fed diet, which increased to $150 \mathrm{ng} /$ $\mathrm{mL}$ during grain adaptation, and Andersen and Jarlov (1990) reported $25 \%$ decline in LPS concentration from the initial range of 150 to $160 \mathrm{ng} / \mathrm{mL}$ during control, after induction of acute acidosis in nonlactating Jersey cows $(320 \mathrm{~kg})$. Earlier studies (Nagaraja et al., 1978a; $1978 b$ ) on rumen LPS in dairy cows were semiquantitative and were based on extraction/purification of LPS from rumen fluid followed by biological assays such as pyrogenicity in rabbit or lethality in mice or chicken embryos. The reactivity of LPS from environmental or anaerobic bacterial sources with these biological assays is 1,000 times less than with the LAL assay (Hurley, 1995). Therefore, a quantitative comparison cannot be made between the earlier studies with ones that are more recent. The discrepancy between our study and those of Andersen et al. (1994b) and Andersen and Jarlov (1990) is probably because of differences in the method of LPS determination. The LAL assay was employed in all of these studies; however, over the past 2 decades, the accuracy of the assay has been improved 
substantially (Hurley, 1995). For example, the original gel clot assay of LAL provided a semiquantitative result, whereas chromogenic endpoint LAL offers quantitative results with a sensitivity of $10 \mathrm{pg} / \mathrm{mL}(0.1 \mathrm{EU} / \mathrm{mL})$ and exhibits less product interference than LAL utilizing the clotting protein. A more recent method is the kinetic chromogenic LAL, which provides a sensitivity as low as $0.5 \mathrm{pg} / \mathrm{mL}(0.005 \mathrm{EU} / \mathrm{mL})$, and a wider range of detection up to $5 \mathrm{ng} / \mathrm{mL}$ (50 EU/mL; Hurley, 1995). Factors such as abrupt, gradual, or repeated induction of SARA, feed intake and rumen absorptive surface/ capacity of individual animals, inclusion rate of NFC in the diet, starch fermentability, and feed particle size can affect the rumen $\mathrm{pH}$, as well as the growth/lysis rate of gram-negative bacteria, and therefore, free LPS level in the rumen. Hence, apart from method of LPS measurement, several differences between animals and diets may also influence the range of free LPS in the rumen.

Despite general agreement that grain-induced SARA increases free rumen LPS, no evidence of LPS in peripheral blood circulation has been found (Gozho et al., 2007). There is also inconsistency in detection of LPS in peripheral circulation during experimentally induced acute ruminal acidosis. Although some studies have occasionally detected LPS in peripheral circulation (Dougherty et al., 1975; Aiumlamai et al., 1992; Andersen et al., 1994b), others were unsuccessful (Andersen and Jarlov, 1990; Andersen et al., 1994a). The fact that LPS is present in low concentrations in peripheral blood plasma and at least a $10 \times$ dilution is required for the LAL assay to control the inhibitors and interfering factors in blood creates challenges to the measurement of LPS when the sensitivity of the assay is low. Using a kinetic LAL assay, we reported here for the first time that a grain-based SARA challenge increased the peripheral plasma LPS from $<0.05$ to $0.52 \mathrm{EU} / \mathrm{mL}(52 \mathrm{pg} / \mathrm{mL})$ across the sampling hours. A continuous presence of a low amount of LPS in peripheral plasma of SARA induced cows could result in a metabolic endotoxemia that triggers a low-grade inflammation compared with acute disorders such as septicemia. In addition, it has been documented that metabolic endotoxemia can result in insulin resistance in the liver, hyperinsulinemia, higher blood glucose level, modification of the energy metabolism, and anorexia (Cani et al., 2007). Moreover, Cani et al. (2007) demonstrated that chronic endotoxemia changes the cells' insulin sensitivity through the function of CD14, a membrane receptor of LPS, and results in BW gain without excessive energy intake in chronic LPS-infused mice. This finding might similarly explain the gain in body condition in mid- to late-lactation dairy cows experiencing SARA (Kleen et al., 2003).
In this study and consistent with the previous reports (Gozho et al., 2007; Emmanuel et al., 2008), the peripheral blood concentrations of SAA and Hp increased after the SARA challenge, and exceeded their physiological ranges for healthy animals. The basal ranges are $<50 \mu \mathrm{g} / \mathrm{mL}$ for $\mathrm{Hp}$ and $<25 \mu \mathrm{g} / \mathrm{mL}$ for SAA in cattle (Tri-Delta Diagnostics Inc., Morris Plains, NJ; Humblet et al., 2006). In response to blood LPS, the concentration of LPS specific acute phase protein LBP was also significantly increased in peripheral blood plasma and milk during SARA. The LBP concentration following the SARA challenge in our study (53.1 $\mu \mathrm{g} / \mathrm{mL}$ ) was higher than that reported by Emmanuel et al. (2008) for dairy cows supplemented with $45 \%$ barley $(<16 \mu \mathrm{g} / \mathrm{mL})$. In control cows, blood SAA concentration was above the physiological level (167 vs. $25 \mu \mathrm{g} / \mathrm{mL}$ ), whereas Hp was not detectable. The difference between the response of SAA and that of Hp status is because of the higher sensitivity of SAA to inflammatory stimuli than $\mathrm{Hp}$ and might be an indicator of an early stage of inflammation (Humblet et al., 2006). Plasma LBP levels of control cows were within the basal range of 10.8 to $37.8 \mu \mathrm{g} / \mathrm{mL}$ previously reported by Suojala et al. (2008) and Bannerman et al. (2003), respectively. These data support our hypothesis that a grain-based SARA challenge increases translocation of LPS into the peripheral circulation and elevates peripheral plasma LBP that facilitate binding of LPS to cell membrane receptors, which then triggers a cascade of events toward a local or systemic inflammatory response and release of other acute phase proteins into the blood.

The present study indicated that LPS translocation occurs after a grain-based SARA challenge. However, the mechanism and the site of translocation remain unknown. Chin et al. (2006) have conducted experiments using intestinal epithelial cell lines and concluded that an abnormal increase in luminal LPS induces cell apoptosis, disrupts tight junction protein zonula occludens- 1 , and increases epithelial permeability in a dose and time dependent manner by increasing the production of nitric oxide. In addition, Cetin et al. (2004) demonstrated that LPS impairs the $\mathrm{pH}$ regulatory system of enterocytes by inhibition of sodium-proton pumps under extracellular acidosis conditions, resulting in cytoplasmic acidification and cellular dysfunction.

However, differences between the composition of epithelium of the rumen, and of the small and large intestine could result in differences in the effect of LPS on the barrier function of the epithelium among these parts of the gastrointestinal tract. Epithelium in the intestine, lung, and kidney has a simple monolayer structure with tight junctions at the apical pole of the cells, whereas rumen epithelium has a multilayer structure with tight junctions located in the middle lay- 
ers, stratum granulosum, and spinosum (Graham and Simmons, 2005). Although the external layer of rumen epithelia has no tight junctions, it may consist of up to 15 cell layers, which may limit the permeability of large molecules such as LPS (Baldwin, 1998). A recent in vitro study by Emmanuel et al. (2007) indicated that LPS translocates across the rumen wall at a greater rate than across the colon wall, and this translocation is $\mathrm{pH}$ independent. However, the rate of translocation was numerically higher at $\mathrm{pH} 5.5$ in the rumen and at $\mathrm{pH} 6.5$ in the colon than at other $\mathrm{pH}$ levels. The concentration of LPS that was added to the mucosal side tissues in this in vitro experiment was $500 \mu \mathrm{g} /$ $\mathrm{mL}$, which is 50 times more than the free rumen LPS concentration after the grain-based SARA challenge. Hence, that may have disrupted the barrier function of the gut to a greater extent than what would have occurred physiologically.

Consistent with a previous report (Gozho et al., 2006), our data indicated that free rumen LPS concentration increased sharply by $6 \mathrm{~h}$ after feeding $(10,965 \mathrm{ng} / \mathrm{mL})$ and reached to its peak at $12 \mathrm{~h}$ postfeeding $(15,135$ $\mathrm{ng} / \mathrm{mL}$ ). In contrast, peripheral LPS concentration in SARA-induced cows did not follow the same pattern and tended to decline to below prefeeding levels until $6 \mathrm{~h}$ postfeeding (31 vs. $43 \mathrm{pg} / \mathrm{mL}$ ) and then started to increase until $12 \mathrm{~h}$ after feeding $(81 \mathrm{pg} / \mathrm{mL})$. The decline of plasma LPS to below prefeeding levels until $6 \mathrm{~h}$ postfeeding, and the delay in its increase until $12 \mathrm{~h}$ after feeding may suggest that the LPS translocation occurs in the lower gut, rather in the rumen. If LPS does not translocate into the blood circulation from the rumen, then peripheral LPS during grain-induced SARA must be translocated through the epithelium of the small or large intestine. However, before arriving to these sites, free rumen LPS will be detoxified in the duodenum, primarily by bile acids (Bertok, 1998). Therefore, the main source of free LPS in the lower gut must originate from the bacterial community of the terminal ileum and the large intestine. If this hypothesis is correct, then the rate of LPS translocation and its peripheral concentration is independent of rumen $\mathrm{pH}$ and free rumen LPS concentration, but depends on factors such as bypassed starch that stimulates LPS release in the terminal ileum and large intestine. In this study, the diet used for the SARA challenge had a greater content of starch than the control diet. The added starch in the SARA diet was in the form of wheat-barley pellets with physical characteristics, such as specific gravity $>1.2$ and $<1.5$ that categorize them in the range of particles with the highest rate of passage (Kaske et al., 1992). Therefore, a considerable portion of starch may have bypassed rumen fermentation. These conditions may intensify the release of free LPS in the lower gut and may trigger a cascade of events toward barrier failure of monolayer epithelial structure of the intestine and the colon as discussed previously. Further research is necessary to understand if the barrier failure, LPS translocation, and inflammatory responses that are seen after a grain-based SARA challenge occur ruminally or postruminally.

\section{CONCLUSIONS}

A grain-based SARA challenge was conducted by replacing $21 \%$ of the DM of TMR of the control diet with wheat-barley pellets. This challenge increased the duration of rumen $\mathrm{pH}$ below 5.6 to above $180 \mathrm{~min} / \mathrm{d}$, which was taken as the threshold for SARA. The SARA challenge reduced the DMI (15\%), milk yield $(3.3 \mathrm{~kg} / \mathrm{d})$, and milk fat $(0.12 \%$ point $)$, but increased the concentration of free LPS in rumen fluid from 2,818 to $10,715 \mathrm{ng} / \mathrm{mL}$. This challenge also increased plasma LPS concentration from $<0.05$ to $0.52 \mathrm{EU} / \mathrm{mL}$. The peripheral blood concentrations of acute phase proteins SAA and Hp as inflammatory markers increased due to the SARA challenge and exceeded their physiological ranges for healthy animals. In response to blood LPS, concentration of LPS-specific acute phase protein LBP also increased in peripheral blood and milk because of the SARA challenge. Our results suggest that a grainbased SARA challenge increases the lysis of rumen gram-negative bacteria, the release of free LPS in the rumen, and the translocation of LPS into the peripheral circulation. The systemic inflammatory response resulting from the SARA challenge could be due to this translocation of LPS.

\section{ACKNOWLEDGMENTS}

This study was supported by grants from Dairy Farmers of Canada (DFC), the Agri-Food Research Development Initiative (ARDI), and the Natural Sciences and Engineering Research Council of Canada (NSERC). The authors thank the staff of the Dairy Research Unit in Glenlea at the University of Manitoba, for maintenance and care of the animals; and technicians, graduate students, and postdoctoral fellows in the Department of Animal Science, University of Manitoba, for lab assistance and technical support during the experiment. Special thanks to Karmin O and Gary Crow (Department of Animal Science, University of Manitoba) for their assistance with laboratory and statistical analyses.

\section{REFERENCES}

Aiumlamai, S., H. Kindahl, G. Fredriksson, L. E. Edqvist, L. Kulander, and O. Eriksson. 1992. The role of endotoxins in induced ruminal acidosis in calves. Acta Vet. Scand. 33:117-127. 
Allen, M. S. 2000. Effects of diet on short-term regulation of feed intake by lactating dairy cattle. J. Dairy Sci. 83:1598-1624.

Andersen, P. H., B. Bergelin, and K. A. Christensen. 1994a. Effect of feeding regimen on concentration of free endotoxin in ruminal fluid of cattle. J. Anim. Sci. 72:487-491.

Andersen, P. H., M. Hesselholt, and N. Jarlov. 1994b. Endotoxin and arachidonic acid metabolites in portal, hepatic and arterial blood of cattle with acute ruminal acidosis. Acta Vet. Scand. 35:223234 .

Andersen, P. H., and N. Jarlov. 1990. Investigation of the possible role of endotoxin, TXA2, PGI2 and PGE2 in experimentally induced rumen acidosis in cattle. Acta Vet. Scand. 31:27-38.

Baldwin, R. L. 1998. Use of isolated ruminal epithelial cells in the study of rumen metabolism. J. Nutr. 128(Suppl.):293S-296S.

Bannerman, D. D., M. J. Paape, W. R. Hare, and E. J. Sohn. 2003. Increased levels of LPS-binding protein in bovine blood and milk following bacterial lipopolysaccharide challenge. J. Dairy Sci 86:3128-3137.

Bertok, L. 1998. Effect of bile acids on endotoxin in vitro and in vivo (physico-chemical defense). Bile deficiency and endotoxin translocation. Ann. N. Y. Acad. Sci. 851:408-410.

Bhandari, S. K., K. H. Ominski, K. M. Wittenberg, and J. C. Plaizier. 2007. Effects of chop length of alfalfa and corn silage on milk production and rumen fermentation of dairy cows. J. Dairy Sci. 90:2355-2366.

Bradford, B. J., and M. S. Allen. 2007. Depression in feed intake by a highly fermentable diet is related to plasma insulin concentration and insulin response to glucose infusion. J. Dairy Sci. 90:38383845 .

Cani, P. D., J. Amar, M. A. Iglesias, M. Poggi, C. Knauf, D. Bastelica, A. M. Neyrinck, F. Fava, K. M. Tuohy, C. Chabo, A. Waget, E. Delmee, B. Cousin, T. Sulpice, B. Chamontin, J. Ferrieres, J. F. Tanti, G. R. Gibson, L. Casteilla, N. M. Delzenne, M. C. Alessi, and R. Burcelin. 2007. Metabolic endotoxemia initiates obesity and insulin resistance. Diabetes 56:1761-1772.

CCAC. 1993. Guide to the Care and Use of Experimental Animals. Vol. 1. 2nd ed. Canadian Council on Animal Care, Ottawa, ON, Canada.

Cetin, S., J. Dunklebarger, J. Li, P. Boyle, O. Ergun, F. Qureshi, H. Ford, J. Upperman, S. Watkins, and D. J. Hackam. 2004. Endotoxin differentially modulates the basolateral and apical sodium/proton exchangers (NHE) in enterocytes. Surgery 136:375-383.

Chin, A. C., A. N. Flynn, J. P. Fedwick, and A. G. Buret. 2006 The role of caspase-3 in lipopolysaccharide-mediated disruption of intestinal epithelial tight junctions. Can. J. Physiol. Pharmacol. 84:1043-1050.

Dosogne, H., E. Meyer, A. Sturk, J. van Loon, A. M. Massart-Leen, and C. Burvenich. 2002. Effect of enrofloxacin treatment on plasma endotoxin during bovine Escherichia coli mastitis. Inflamm. Res. $51: 201-205$.

Dougherty, R. W., K. S. Coburn, H. M. Cook, and M. J. Allison. 1975. Preliminary study of appearance of endotoxin in circulatory system of sheep and cattle after induced grain engorgement. Am. J. Vet. Res. 36:831-832.

Emmanuel, D. G. V., S. M. Dunn, and B. N. Ametaj. 2008. Feeding high proportions of barley grain stimulates an inflammatory response in dairy cows. J. Dairy Sci. 91:606-614.

Emmanuel, D. G. V., K. L. Madsen, T. A. Churchill, S. M. Dunn, and B. N. Ametaj. 2007. Acidosis and lipopolysaccharide from Escherichia coli B:055 cause hyperpermeability of rumen and colon tissues. J. Dairy Sci. 90:5552-5557.

Giger-Reverdin, S. 2000. Characterization of feedstuffs for ruminants using some physical parameters. Anim. Feed Sci. Technol. 86:5369.
Gozho, G. N., D. O. Krause, and J. C. Plaizier. 2006. Rumen lipopolysaccharide and inflammation during grain adaptation and subacute ruminal acidosis in steers. J. Dairy Sci. 89:4404-4413.

Gozho, G. N., D. O. Krause, and J. C. Plaizier. 2007. Ruminal lipopolysaccharide concentration and inflammatory response during grain-induced subacute ruminal acidosis in dairy cows. J. Dairy Sci. 90:856-866.

Gozho, G. N., J. C. Plaizier, D. O. Krause, A. D. Kennedy, and K. M. Wittenberg. 2005. Subacute ruminal acidosis induces ruminal lipopolysaccharide endotoxin release and triggers an inflammatory response. J. Dairy Sci. 88:1399-1403.

Graham, C., and N. L. Simmons. 2005. Functional organization of the bovine rumen epithelium. Am. J. Physiol. Regul. Integr. Comp. Physiol. 288:R173-R181.

Horadagoda, N. U., K. M. Knox, H. A. Gibbs, S. W. Reid, A. Horadagoda, S. E. Edwards, and P. D. Eckersall. 1999. Acute phase proteins in cattle: Discrimination between acute and chronic inflammation. Vet. Rec. 144:437-441.

Humblet, M. F., H. Guyot, B. Boudry, F. Mbayahi, C. Hanzen, F. Rollin, and J. M. Godeau. 2006. Relationship between haptoglobin, serum amyloid $\mathrm{A}$, and clinical status in a survey of dairy herds during a 6-month period. Vet. Clin. Pathol. 35:188-193.

Hurley, J. C. 1995. Endotoxemia: Methods of detection and clinical correlates. Clin. Microbiol. Rev. 8:268-292.

Kaske, M., S. Hatiboglu, and W. V. Engelhardt. 1992. The influence of density and size of particles on rumination and passage from the reticulo-rumen of sheep. Br. J. Nutr. 67:235-244.

Kleen, J. L., G. A. Hooijer, J. Rehage, and J. P. Noordhuizen. 2003. Subacute ruminal acidosis (SARA): A review. J. Vet. Med. A Physiol. Pathol. Clin. Med. 50:406-414.

Krause, K. M., and G. R. Oetzel. 2005. Inducing subacute ruminal acidosis in lactating dairy cows. J. Dairy Sci. 88:3633-3639.

Nagaraja, T. G., E. E. Bartley, L. R. Fina, H. D. Anthony, and R. M. Bechtle. 1978a. Evidence of endotoxins in the rumen bacteria of cattle fed hay or grain. J. Anim. Sci. 47:226-234.

Nagaraja, T. G., E. E. Bartley, L. R. Fina, H. D. Anthony, S. M. Dennis, and R. M. Bechtle. 1978b. Quantitation of endotoxin in cell-free rumen fluid of cattle. J. Anim. Sci. 46:1759-1767.

Nagaraja, T. G., and K. F. Lechtenberg. 2007. Acidosis in feedlot cattle. Vet. Clin. North Am. Food Anim. Pract. 23:333-350. (viii-ix.).

Oba, M., and M. S. Allen. 2003. Extent of hypophagia caused by propionate infusion is related to plasma glucose concentration in lactating dairy cows. J. Nutr. 133:1105-1112.

Owens, F. N., D. S. Secrist, W. J. Hill, and D. R. Gill. 1998. Acidosis in cattle: A review. J. Anim. Sci. 76:275-286.

Plaizier, J. C., D. O. Krause, G. N. Gozho, and B. W. McBride. 2008. Subacute ruminal acidosis in dairy cows: The physiological causes, incidence and consequences. Vet. J. 176:21-31.

SAS Institute. 2004. SAS/STAT Users Guide. Release 9.1.2. SAS Inst. Inc., Cary, NC.

Sriskandan, S., and D. M. Altmann. 2008. The immunology of sepsis. J. Pathol. 214:211-223.

Suojala, L., T. Orro, H. Jarvinen, J. Saatsi, and S. Pyorala. 2008 Acute phase response in two consecutive experimentally induced E. coli intramammary infections in dairy cows. Acta Vet. Scand. 50:18-27.

Waldron, M. R., T. Nishida, B. J. Nonnecke, and T. R. Overton. 2003. Effect of lipopolysaccharide on indices of peripheral and hepatic metabolism in lactating cows. J. Dairy Sci. 86:3447-3459. 